Gästredaktionens förord

\title{
Småland och litteraturen
}

\author{
Piia K. Posti och Peter Forsgren
}

Finns det en småländsk litteratur och hur skulle dess historia i så fall kunna berättas? Består den småländska litteraturen i själva verket av en rad olika litterära traditioner som är beroende av skiftande och ibland mycket särpräglade historiska, kulturella, religiösa, ekonomiska och sociala villkor på lokal och regional nivå? I vilken utsträckning har dessa präglat den litteratur som vuxit fram i landskapet och omvänt - i vilken utsträckning har bilden av Småland formats av litteraturen?

Vi är en grupp litteraturforskare huvudsakligen verksamma vid Linnéuniversitetet som börjat ställa oss dessa och liknande frågor med målet att så småningom tillsammans skriva en småländsk litteraturhistoria. Artiklarna i detta nummer av HumaNetten får ses som ett första steg i riktning mot detta större litteraturhistorieprojekt och de ger exempel på olika ingångar till den småländska litteraturen, till dess mångskiftande historia och traditioner.

I de diskussioner vi hittills fört har en rad olika bilden av landskapet och dess litteratur tonat fram: Småland som Glasriket och IKEA-land, som Gnosjöandans hemvist, ett landskap befolkat av småföretagare och entreprenörer liksom av idoga bönder och torpare, med starka religiösa traditioner, såväl frireligiösa som högkyrkliga, med mera, med mera. Vi har också kunnat konstatera att bilden av Småland i hög grad också skapats genom litteraturen, av författare som Astrid Lindgren, Vilhelm Moberg, Pär Lagerkvist och Elin Wägner, för att nämna några av de främsta. Dessa liksom en rad andra författare har tillsammans gett en mycket mångskiftande och på flera sätt motsägelsefull bild av Småland, något som artiklarna i detta tidskriftsnummer tydligt visar. Denna litterära komplexitet och rikedom blir viktig att lyfta fram i den kommande litteraturhistorien.

Här följer en kort presentation av artiklarna i detta nummer och hur de på olika sätt belyser vad en småländsk litteratur skulle kunna vara. Peter Forsgrens "Iakttagelser, hågkomster och reflexioner" tar upp tre klassiska svenska författare, Carl von Linné, Samuel Ödman och Esaias Tegnér, och går tillbaka till den tid, till de historiska epoker vi brukar kalla upplysning och romantik, då den moderna gestaltningen av Småland kanske kan sägas ta sin början. Det rör sig om en period då det starka intresset för att börja utforska naturen, historien och kulturen gick hand $\mathrm{i}$ hand med intresset för det egna jaget. Det är som artikeln visar märkbart i dessa tre författares texter liksom 
att bilden av Småland i dem har olika utgångspunkter och därmed också olika utseenden.

Med Asa-Hanna (1918) inledde Elin Wägner raden av de så kallade smålandsromanerna som avslutades med hennes sista roman Vinden vände bladet (1947). Asa-Hanna intar på flera sätt en central plats i författarskapet och den filmades 1946 i regi av Anders Henriksson och med Aino Taube och Edvin Adolphsson i den kvinnliga respektive manliga huvudrollen. Dagmar Brunow visar i sin artikel "Var ligger biodukens Småland? Hur Elin Wägners Asa-Hanna blev film" hur filmen växte fram i ett samarbete mellan Elin Wägner, manusförfattaren Barbro Alving, regissör och skådespelare. Detta samarbete resulterade $i$ att en del av romanens småländska karaktär, inte minst inslagen av dialekt $\mathrm{i}$ dialogerna, togs bort.

Elin Wägners roman Åsa-Hanna speglar brytningen mellan tradition och modernitet på den småländska landsbygden i början av 1900-talet. Temat är också centralt i Pär Lagerkvists roman Gäst hos verkligheten (1925), även om större delen av handlingen i den utspelas i en stad med drag av Växjö. I sin artikel "Växjöroman eller Växjö som fond för inre skeenden?" följer Magnus Eriksson huvudpersonen Anders brottning med familjens traditionspräglade liv och kamp för att forma sin egen identitet. I detta sammanhang diskuterar Eriksson den roll Växjö spelar inte bara i Lagerkvists roman utan även hos andra författare som Johannes Anyuru och Nike Krantz.

Det var inte bara i sina romaner som Elin Wägner skildrade den småländska landsbygdens förvandlingar. Så sker även i novellsamlingen Gammelrödja (1931) som har undertiteln Skildringar från en bygd som ömsar skinn. I en analys av novellen "Käringamötet", med titeln "Bländas ömkliga ättlingar eller det inhiberade käringamötet hos Elin Wägner", visar Inger Littberger Casiou-Rousseau hur detta gestaltas både på en tematisk och berättarteknisk nivå i texten.

Likt Elin Wägner och Pär Lagerkvist tillhör Vilhelm Moberg de författare som genom sina verk lämnat viktiga bidrag till bilden av Småland $\mathrm{i}$ litteraturen. Åsa Nilsson Skåve visar i sin artikel "'Ett fäste i världen' Vilhelm Mobergs Din stund på jorden" vilken viktig roll det småländska barndomslandskapet spelar i huvudpersonens retrospektiva berättelse. Artikeln lyfter också fram kampen mellan traditionens krav och individens frihet som ett viktigt tema i romanen, men också att den rymmer en maktkritik med globala dimensioner.

Barndomslandskapet återkommer vi till i Arne Johnssons diktning men utifrån ett mystiskt och existentiellt perspektiv. I "Arne Johnsson. Mader, minnen, mystik" belyser Niklas Schiöler hur Johnssons småländska barndomsbild och landskap är av ett "sonderande" slag, och utmärks av "grundingredienser" som de "rustika tingen" (huggkubbar, vedkapar) och lantliga dunster, men även av "en del råare stråk". I detta bidrag aktualiseras våra för historieskrivandet betydelsefulla frågor om när en författare blir eller upphör att vara småländsk och vad som gör en författare just småländsk. 
Att Småland och barndom är starkt förknippade ser vi i fler artiklar i numret. Eva Söderbergs "Martha Sandwall-Bergströms väg till flickböckerna. Litteratur och läsning i en småländsk barndom" tar sin utgångspunkt i hur artikelförfattarens bild av Småland bland annat formats genom litteraturen för att sedan fördjupa sig i Kulla Gulla-serien och författarskapet. Söderberg visar även vilken betydelse den religiösa bakgrunden och det muntliga berättandet haft för Sandwall-Bergström.

Astrid Lindgren går knappast att förbises i detta barndomssammanhang, men vilken bild av Småland finner vi Astrid Lindgrens tidiga författarskap? Både Hanna Liljeqvist och Helene Ehriander belyser detta genom Lindgrens tidiga flickböcker. I "Brev från den lilla, lilla staden. Skildringen av småstaden i Astrid Lindgrens Britt-Marie lättar sitt hjärta" undersöker Liljeqvist hur bilden av Småland framträder i Lindgrens debutroman. Förutom att ge en genomlysning av bokens bakgrund och genrerelation, visar Liljeqvist hur den anonyma småstadsmiljön förknippas med och läses som en mindre stad i Småland genom Lindgrens val av symbolik och de associationer läsningen ger i förhållande till Vilhelm Mobergs och Lindgrens övriga smålandsskildringar.

Flickboken, barndomen och den nostalgi som barndomstemat gärna lånar sig till belyses vidare av Helene Ehriander i "Idyll på småländska landsbygden. Astrid Lindgrens flickbok Kerstin och jag (1945)”. Ehriander använder sig av Svetlana Boyms nostalgibegrepp restorative och reflective nostaglia för visa hur Lindgren genom protagonistens pappa och dennes längtan till sitt barndomshem på landsbygden använder sig av en särskild form av nostalgi för att skildra den småländska lantlivsidyllen. Artikeln belyser också boken ur ett tidsperspektiv och beskriver hur omslagsbilderna förändrats över tid, och hur berättelsen bearbetats till den senare utgåvan från 1954.

Medan det är arbetes glädje och den småländska bondens strävsamhet som betonas av Lindgren i Kerstin och jag, visar Martin Hellström i "'Éta' och 'lésa': förrådd av dialekten" hur svensk barn- och ungdomslitteratur också skapat bilden av Småland som ett "sommarlovets kungarike". Men frånvaron av småländska dialekter "stjälper upplevelsen av det autentiska" i framställningarna. Här breddas bilden av Småland genom Hellströms val att reflektera över ljudet av Småland genom barns öron i ett projekt om radioteaterversionen av Maria Gripes Tordyveln flyger i skymningen. Hur viktig är dialekten för att skapa autenticitet?

Frågan om äkthet och autenticitet dryftas även av Vilhelm Moberg och Gertrud Lilja. I Maria Nilsons artikel "'Och få tala fritt från hjärtat' brevväxlingen mellan Gertrud Lilja och Vilhelm Moberg 1928-1941" visar Nilson att Småland blir utgångspunkten för vänskapen mellan författarna. Inte minst Lilja betonar deras gemensamma bakgrund och kännedom om trakten. Ett genomgående tema i brevväxlingen är frågan om "äkthet” och vad det innebär att vara en "äkta" smålänning. Brevväxlingen är litteraturhistoriskt 
intressant eftersom den visar att båda författarna uppehållit sig vid frågan om hur en "äkta" smålandsskildring bör se ut.

Kännedom om trakten och det lokala igenkännandet kan vara en betydelsebärande komponent både för författarna och deras läsare. I numrets två avslutande artiklar får vi läsa om två författare vars författarskap förknippas med de småländska orterna Ljungby respektive Huskvarna. I Anna Salomonssons artikel "Småland och världen i några verk av Ann Margret Dahlqvist-Ljungberg" möter vi åter småstaden och Linné som viktiga motiv. Denna gång med Ljungby som förlaga. Hos Dahlqqvist-Ljungberg satiriseras både Linnés "självhybris" och småstadslivet med de "småborgerliga ideal som präglar stadsandan". Småland speglas även i "samröret mellan den lilla världen och den stora", i det globala och i evigheten. Samtidigt visar Salomonsson på förekomsten av mer traditionella bilder av det småländska landskapet i Fahlqvist-Ljungbergs diktning: det småländska torpet i skogsgläntan vid tjärnen som väcker "nostalgi och sympati".

I numrets sista bidrag möter vi samtidens och populärlitteraturens bild av den småländska bygden, som diskuteras av Piia K. Posti i artikeln "Kärleksaffärer och kvinnliga entreprenörer: Ewa Klingbergs Huskvarnasviten". Hos Klingberg är den lokala förankringen i Småland och Huskvarna central, ända ner på gatunamnsnivå. Men även om lantidyllen och typiska smålandspigor och drängar förekommer, är det en annan sida av det småländska lynnet som dominerar: entreprenörskapet. Posti argumenterar för att Klingberg uppdaterar den etablerade, manligt kodade bilden av den småländska entreprenören genom att hon "skriver fram" de kvinnliga entreprenörerna "ur historien" och i samtiden. 